MARKO JESENŠEK: THE SLOVENE LANGUAGE IN THE ALPINE AND PANNONIAN LANGUAGE ARIA. THE HISTORY OF THE SLOVENE LANGUAGE. Kraków: Towarzystwo Autorów i Wydawców Prac Naukowych Universitas, 2005. 365 str.

Monografija The Slovene Language in the Alpine and Pannonian Language Aria s podnaslovom The history of the Slovene Language avtorja Marka Jesenška, priznanega raziskovalca jezikovnozgodovinskih oz. jezikovnorazvojnih vprašanj, je izšla v Krakovu leta 2005. Recenzent je bil Emil Tokarz, korekture je opravil Brian Halliday, za prevod pa je poskrbela Heather Pirjevec. Delo, ki s temeljito obravnavo slovenskih jezikovnih prelomnic $\mathrm{v}$ angleškem jeziku presega ozek nacionalni znanstveni prostor, je členjeno na dva obsežnejša sklopa, ob tem pa vsebuje še uvod, povzetek v slovenščini in poljščini, uporabljene vire in literaturo, izčrpno imensko kazalo ter kratko predstavitev avtorja.

V prvem sklopu Prekmurian Standard Language (Prekmurski knjižni jezik), ki prinaša enajst poglavij, avtor utemeljuje delitev knjižne slovenščine na dve različici, osrednjeslovensko in vzhodnoslovensko, ki sta soobstajali vse do jezikovne združitve sredi 19. stoletja (neformalno pa še dlje). Osrednjeslovenska različica je vezana na alpski prostor z večstoletno pisno tradicijo, vzhodnoslovenska, ki se zaradi politične razdelitve jezikovno enotnega prostora deli na vzhodnoštajerski in prekmurski jezik, pa predstavlja kontinuiteto z nekdanjo panonsko slovenščino. V poglavju Standard Variants in the Slovene Language Area (Knjižne različice v slovenskem jezikovnem območju) avtor podaja sistematičen pregled slovenskega jezikovnega razvoja in pri tem izhaja iz znanstvenih ugotovitev Martine Orožen (1996a), ki jih raziskovalno dopolnjuje in nadgrajuje z lastnimi spoznanji o starocerkvenoslovanskih vplivih na t. i. panonsko različico (npr. deležijsko izražanje istodobnosti in preddobnosti). Opozarja tudi na pretežno enosmerne stike med obema sistemoma, saj v slovenskem osredju vzhodnoslovenske knjižne tradicije niso poznali vse do 19. stoletja.

Sklop se nadaljuje z zanimivo in izvirno kontrastivno obravnavo slovenskega in slovaškega jezika (Connecting Points in the Formation of the Slovak and Prekmurje Standard Language), ki sta se po priključitvi v Ogrsko kraljestvo znašla $v$ podobnem jezikovnozaviralnem položaju znotraj narodnostno mešane države. Avtor izpostavlja pomen znamenitega bratislavskega liceja, na katerem so imeli prekmurski protestanti, med katerimi je potrebno poudariti Števana Küzmiča in Mihala Bakoša, možnost spoznavati težnje po oblikovanju slovaškega knjižnega jezika. Oba jezika, slovaščina in prekmurščina, sta - kot ugotavlja Jesenšek - do lastnega normiranja uporabljala t. i. nadomestna jezika, češčino oz. kajkavščino. Naslednjo podobnost avtor najde $\mathrm{v}$ jezikovno neenotni podlagi, razcepljeni na posamezne govore, na osnovi katere sta se oba jezika normirala kot nadnarečni tvorbi. Poudari tudi pomembno razliko obeh jezikov, ki izhaja iz zavedanja prekmurskih Slovencev o narodnostni enotnosti s Slovenci alpskega prostora oz. avstrijskega dela tedanje monarhije in neproduktivnega jezikovnega razlikovanja v času ideje o Zedinjeni Sloveniji; jezikovne razmere so bile na Slovaškem drugačne in so vodile v nastanek samostojnega slovanskega jezika. 
V nadaljevanju se avtor ustavlja ob vprašanju prekmurskega jezika, kakor se je med letoma 1919 in 1921 kazal v prispevkih Božidarja Borka v Murski straži, "glasilu obmejnih Slovencev« (Borko and the Problem of the Prekmurian Language Variant). Borko je kot dober poznavalec kulturnih, političnih in zgodovinskih dejstev odlično razumel razvoj te knjižne različice in zagovarjal njeno postopno prehajanje $\mathrm{v}$ enotno slovenščino, kar je v monografiji ponazorjeno z nazornimi citati. Po letu 1919 se je Borko na časopisnih straneh zavzemal za jezikovno in politično združitev Slovencev obeh strani reke Mure, ki ji je pripisoval povezovalno in ne razdruževalno vlogo. Jesenšek ugotavlja, da je prekmurski jezik razumel kot »enakovredno in vzporedno knjižno različico osrednjeslovenskemu« jeziku, ki pa jo je na pragu 20. stoletja, ko govorimo le še o narečju, potrebno nadomestiti z enotnim slovenskim knjižnim jezikom.

Avtor monografije se nato tematsko osredotoča na jezik prekmurskih šolskih knjig (Language in the $19^{\text {th }}$ Century Prekmurje Spelling and Textbooks), s posebnim ozirom na njihove glasoslovno-oblikoslovne značilnosti in na oblikovanje strokovnega jezika. V primerjalni analizi Agustičevega Prirodopisa in Erjavčevih Domačih in tujih živali $v$ prispodobah ugotavlja prepletanje $\mathrm{z}$ umetnostnim jezikom in nekatere zanimive besedotvorne rešitve Agustičevega besedila, izhajajoče iz panonske jezikovne baze. V tiskih druge polovice 19. stoletja Jesenšek prepoznava dvojnost: odprtost katoliških prekmurskih piscev za sprejem strokovnega izrazja enotnega slovenskega jezika, s čimer so se potrdili pozitivni prekmurskoosrednjeslovenski stiki, ter zavračanje jezikovnega poenotenja in vztrajanje pri prekmurskem narečju pri protestantih na drugi strani.

Jezikovna analiza prekmurskega učbeniškega tiska se nadaljuje pod naslovom Etymological Characteristics of the Prekmurje Language Variant. Besedoslovne značilnosti prekmurskega knjižnega jezika avtor prikazuje na primeru prekmursko-madžarskega slovarčka v Küzmičevem abecedniku ABC kni'sicza na narodni soul haszek (1790), v katerem prevladuje izvirno prekmursko besedje, redke izposojenke pa so prilagojene prekmurski normi. Primerjalna analiza s podobnim vzhodnoštajerskim slovarčkom je pokazala prekrivnost jedrnega besedja slovenskega severovzhoda.

Sledi pet poglavij, vezanih na prekmursko časopisje, ki ga Jesenšek raziskuje z doslej spregledanega jezikovno-publicističnega vidika. Jezikovna analiza v poglavju Forming the Journalistic Language in the Slovene Pannonian Language Territory potrjuje, da se je prekmurski knjižni jezik pojavil tudi v publicistiki, čeprav se zaradi nenaklonjenega časa ni mogel do popolnosti razviti in uveljaviti; avtorjeve analize štirih prekmurskih časopisov (Prijatel, Kalendar, Marijin list, Novine) omogočajo spoznanje, da so prekmurski tiski prešli iz knjižnega v narečni okvir postopoma, in sicer šele proti koncu 19. oz. v začetku 20. stoletja.

$\mathrm{V}$ raziskavi jezika prvega prekmurskega časopisa Prijatel (The Language of the First Prekmurian Newspaper Prijatel) Jesenšek opozarja na raznolike časopisne rubrike, ki so skušale zadovoljevati »potrebe širokega bralskega kroga«, na Agustičev odnos do ogrskih Slovencev in njihovega jezika, z izbranimi citati predstavlja tudi Agustičeva razmišljanja o maternem in državnem jeziku. Raziskal je razmerje med tvor- 
cem besedila in naslovniki (kot opaža, je bila komunikacija v časopisu vse do 4 . letnika pretežno enosmerna). Zanimivo gradivo predstavljajo iz časopisa izpisani prekmurski frazemi, npr. postaviti na poplate, prinesti v guč, biti do teo bos, biti za dojno kravo, biti v čakajočem stališi, in vremenski pregovori, saj nas nanje ne opozarja noben prekmurski slovar. Avtor je prvi, ki je iz časopisa izpisal značilno panonsko besedje in ga razvrstil $\mathrm{v}$ posamezne pomenske skupine ter opozoril na Agustičeve (ne) sistemske novotvorbe. Pomembne ugotovitve je prinesla analiza glasoslovnooblikoslovne ravni v časopisu Prijatel, na podlagi katere je bila ugotovljena »nadnarečna jezikovna raba«.

Zanimive izsledke prinaša tudi poglavje o pisavi zemljepisnih imen $\mathrm{v}$ časopisu Prijatel (The Writing of Geographical Names in the First Prekmurian Newspaper Prijatel), ki je pokazalo, da se je Agustič odločil za slovenjenje vseh naselbinskih imen, pri tem pa je postavil trdna pravopisna pravila, npr. za pisanje velike oz. male začetnice, za pisavo skupaj in narazen, pri glasoslovnih, oblikoslovnih in predvsem besedotvornih rešitvah pa je opazno omahovanje med knjižno normo in narečjem (123). Za zapis nenaselbinskih imen je, kot opaža Jesenšek, značilna nesistematičnost, nenormativnost.

Avtor se v tem sklopu posveča tudi oglaševalskim besedilom (Tradition and Modernism in Prekmurian's Advertising Texts) in s stilistično ter $\mathrm{z}$ jezikovnoprimerjalno analizo v obdobju štiridesetletnega izhajanja Kalendarja srca Jezušovoga ugotavlja tradicionalne in moderne prvine oglaševalskega jezika. Slednje so vezane na: (1) rabo slovenskega knjižnega jezika namesto arhaičnega prekmurskega, (2) zamenjavo madžarskega črkopisa s slovenskim,
(3) zavračanje panonizmov in tudi madžarizmov ter (4) nastanek prekmurskega pogovornega jezika (134).

Časopisni del avtor sklene s preglednim prikazom prekmurskega publicističnega jezika v prvi polovici 20. stoletja (Prekmurian Journalistic Language in the First Half of the $20^{\text {th }}$ Century), $\mathrm{v}$ katerem poudari preplet sporočanjske, vplivanjske in zabavne vloge publicističnih besedil, ki so vezana na naslednje novinarske vrste: vest, novica, poročilo, uvodnik, komentar in oglasi.

Sklop zaključuje Jesenškova raziskava Škrabčevega videnja vloge posameznih deželnih in pokrajinskih jezikov pri oblikovanju knjižne slovenščine (Škrabec about the Share of Provinces and Regions in Norm of the Slovene Literary Language). Temelj slovenske knjižne norme mu predstavlja osrednjeslovensko knjižnojezikovno izročilo, vpliv nesrediščnih govorov nanj pa se Škrabcu zdi dopusten le v primeru, če osrednjemu »kranjskemu jeziku« ne nasprotujejo (153).

Sklop Eastern Styrian Standard Language (Vzhodnoštajerski knjižni jezik), sestavljen iz trinajstih poglavij, se začenja z Riglerjevim jezikovnozgodovinskim in dialektološkim pogledom na vzhodnoštajerski jezik v luči treh poskusov normiranja vzhodnoštajerskega jezika kot knjižnega (Rigler's Contribution to the Understanding of the Cultural and Language Situation in Styria). Na podlagi analiziranih razprav avtor prepoznava Riglerjevo zavračanje separatističnih teženj (ki so se začele s prevodi Parhamerjevega katekizma, svetourbansko akademijo, z Volkmerjem in Danjkom) ter njegovo zagovarjanje enotne slovenske knjižne norme.

Skladenjske značilnosti slovenskih prevodov evangelijev obravnavata na- 
slednji dve poglavji: Greek, Latin and German Syntactic influence on Slovene Gospel Translations in the $18^{\text {th }}$ Century in Present Active Participles Ending in - $\check{c}$ and Past Active Participles Ending in -ši in Slovene Translations of Gospels. $\mathrm{V}$ prvem so podani grški, latinski in nemški skladenjski vplivi, v drugem, osredotočenem na deležja in deležnike na -č in -ši, pa je problematika osvetljena na podlagi Oblakovih razprav o tem vprašanju. Skladenjskemu strnjanju je posvečena tudi analiza Murščevega Bogočastja sv. katoliške cerkve, ki je pokazala, da so imeli pisci slovenskega panonskega jezikovnega prostora prirojen občutek za rabo oblik na -č in -ši (238), kar je ponazorjeno s izpisanimi zgledi.

V poglavju Some Morphologicalsyntax Characteristics of the Eastern Styrian Standard Language of the $19^{\text {th }}$ Century, ki ga odlikujejo številni izpisi iz primarnih virov, avtor predstavlja arhaične oblikoslovno-skladenjske prvine vzhodnoštajerskega knjižnega jezika, značilne za vodilne vzhodnoštajerske pisce (tj. Danjka, Šerfa, Laha in Rižnerja, delno Krempla). Posebno pozornost avtor posveča panonskemu tipu zanikanja, strnjevanju povedi z rabo deležnikov in deležij, rabi nedoločnika in namenilnika ter pasivnih zgradb.

Monografija vsebuje tudi izčrpen pregled slovaropisja na Štajerskem, ki mu je dodan tabelarni prikaz (243). Vzhodnoštajerski slovarji, ki so večinoma ostali $\mathrm{v}$ rokopisu (natisnjena sta bila zgolj Čebulov in Murkov slovar) so po Jesenškovih ugotovitvah pripomogli k soočanju značilnega osrednje- in vzhodnoslovenkega besedja ter sredi 19. stoletja pomagali pri oblikovanju t. i. novoslovenščine.

Slovarskemu gradivu so posvečena tudi naslednja tri poglavja. Avtor najprej predstavlja rezultate raziskave slovenskega gradiva v Apostlovem slovarju, tj. najstarejšem ohranjenem rokopisnem slovarju vzhodnoštajerskega področja (Slovene Material in Apostel's Dictionary). Ugotavlja, da med 55524 slovenskimi besedami prevladujejo štajerske in prekmurske, opazna pa je tudi (nezavedna) težnja po preraščanju narečja (278). Jesenšek natančneje prikazuje posamezne pomenske skupine (npr. norec, pijanec, ženska), posebno pozornost pa posveča tudi pregovorom in zanimivim primeram, ki so odslikavale življenje v tedanji Vindiji, tj. današnji slovenski Štajerski.

V Pleteršnikovem slovarju, ki predstavlja izhodišče mnogih jezikoslovnih raziskav, je zajeto tudi Volkmerjevo besedje, ki ga Jesenšek v poglavju Volkmer's Words in Pleteršnik's Dictionary analizira glede na kvalifikatorske oznake (Volk., Volk.-M/Volk.-Mik., Volk.-C., Volk.-Pjk.), glasoslovno-oblikoslovno zgradbo in izvor. Analiza omogoča ugotovitev o Vokmerjevem prizadevanju, da bi na prelomu 18 . in 19. stoletja v svojih posvetnih verzifikacijah presegel narečje in oblikoval besedišče, značilno za nastajajočo vzhodnoštajersko knjižno različico.

Vraz's Enties into Murko's Dictiona$r y$ nam razkriva manj znano dejstvo, da je Stanislav Vraz, kasneje prepoznaven po svoji ilirski usmerjenosti, na posebej uvezane prazne liste pripisoval besede v slovensko-nemški del Murkovega slovarja iz leta 1833. Besedje, ki ga Jesenšek natančno analizira, je prišlo tudi v Pleteršnikov slovar, a ni pripisano Vrazu, temveč ima večinoma oznako vzhodnoštajersko.

Avtor se loteva tudi pravopisnih vprašanj prvega obsežnejšega zgodovinskega dela v slovenščini, tj. Kremplovih Dogodivšin štajerske ze- 
mle, $\mathrm{v}$ katerih najdemo vsebinsko in jezikovno-slogovno pogojeno približevanje vzhodnoštajerski knjižni normi, kljub Kremplovemu siceršnjemu sledenju osrednjeslovenskemu knjižnemu jeziku. Pomembna je ugotovitev, da je Krempl v Dogodivšinah postavil sprejemljiv pravopisni sistem, ki je bil tudi izhodišče Marnovih, Janežičevih in Levčevih razmišljanj o pisavi velike začetnice.

Avtor monografije se v tem sklopu osredotoča tudi na Slomškovo jezikovnonazorsko usmeritev, ki je predstavljala kompromis med njegovim jezikovnim čutom in jezikovno odprtostjo (312) - Slomšek se je namreč zavzemal za postopno približevanje obeh knjižnih norm in preraščanje $\mathrm{v}$ enoten slovenski knjižni jezik. Jesenšek na osnovi jezikovne priredbe Slomškovih pridig, ki jo je pripravil leta 2000, raziskuje tudi Slomškov slog, ki izstopa po iskrivosti in živosti - slednjo dosega s pomočjo stalnih rekel, novotvorb, skladenjskega strnjanja, stilno zaznamovanega besednega reda, skladenjskega kopičenja, dramatičnega sedanjika itd.

Predstavljena je tudi zanimiva izraba sopomenskosti v Cafovem prevodu Robinsona Mlajšega (Synonym Use in the Vocabulary of Caf's Translation od Robinson Mlajši), v katerem je zaradi prevajanja iz češčine opazna slovensko-češka sopomenskost ter besedni in skladenjski čehizmi (331). Ob dvojnični sopomenskosti se pojavljajo tudi daljši sopomenski nizi, v katerih Caf združuje istopomensko besedje, npr. les - šuma - hosta - goša - češa (325), in sicer z namenom bralcem približati besedje različnih slovanskih jezikov in nakazati njihovo možnost združevanja.

Monografija je sklenjena $\mathrm{z}$ avtorjevimi razmišljanji o povezavi jezikovne preteklosti s sedanjostjo (Ties between the Past and Present), zlasti z ozirom na šolski sistem. Avtor najde mnoge odgovore na aktualna vprašanja že v 19. stoletju, npr. pri Miklošiču (334), človeku, ki je premišljeno in odgovorno načrtoval jezik. Jesenšek ob včlanitvi v Evropsko zvezo poudarja pomembno vlogo jezikovne politike in spodbuja duhovno, kulturno ter jezikovno ustvarjalnost, na podlagi katere bo strah o nadaljnjem obstoju slovenščine odveč.

Po kratkem pregledu $\mathrm{v}$ monografiji The Slovene Language in the Alpine and Pannonian Language zajete problematike lahko zaključim, da Jesenšek izčrpno obravnava vsa relevantnejša prekmurska in vzhodnoštajerska besedila ter vse pomembnejše avtorje tega področja (Borko, Kuzmič, Škrabec, Rigler, Muršec, Apostel, Volkmer, Vraz, Krempl, Slomšek, Caf). Z jezikovnozgodovinskega vidika se dotika obeh socialnih zvrsti (knjižne in narečne) in zajema funkcijskozvrstno različna besedila. Razrešuje jezikovna vprašanja vseh jezikovnih ravnin, metodološko pa raziskavo odlikuje preplet različnih pristopov, od jezikovnoanalitičnega, sintetičnega, kontrastivno-primerjalnega, do sociolingvističnega. Avtor na podlagi jezikovnozgodovinskih spoznanj ovrednoti sinhrono jezikovno stanje in poda pogled v slovensko jezikovno prihodnost. Zaradi vsega naštetega monografija predstavlja aktualno in pomembno izhodišče nadaljnjih jezikovnorazvojnih raziskav ter kanonizirano delo pri študiju slovenske jezikovne zgodovine zaradi angleškega metajezika zlasti na tujih univerzah.

\section{Natalija Ulčnik,}

Univerza v Mariboru, Filozofska fakulteta, natalija.ulcnik@uni-mb.si 